\title{
Equity, Land Tenure and HIV/AIDS Opportunity and Risk in Namibian Agricultural Sector
}

\author{
Be Well San Miguel* \\ Namibian case study, Written for USAID Policy in Action, USA
}

Submission: March 12, 2017; Published: May 09, 2018

*Corresponding author: Be Well San Miguel, Namibian case study, Written for USAID Policy in Action, USA, Email: deborah@bewellsanmiguel.com

\section{Opinion}

The southern African country of Namibia is burdened with a profound inequity in the distribution of income inherited from its recent colonial past. According to the World Bank it is currently one of the least equitable economies in the world. It is also experiencing a devastating HIV/AIDS epidemic...again ranking with the top five countries in sero -prevalence according to the 2004 UNAIDS report on the global AIDS epidemic. Driving along its super highways, gorgeous national parks and well-developed cities and towns, it is hard to reconcile those harsh realities to the sense of prosperity that greets the casual observer or tourist.

Namibia is rich in natural resources with diamonds and uranium sales underpinning its diverse mining industry. Agriculture is the second largest economic base, with about 4,000 , mostly white, commercial farmers owning nearly half of the arable land. In nearby Zimbabwe with a similar history of inequitable land distribution, impatience with the slow pace of land reform has lead to whole sale land seizures resulting in economic chaos in a country previously known as the "breadbasket" of eastern and southern Africa. Namibian landowners are viewing this scenario nervously and hope the government acts decisively, albeit moderately, before the country erupts into violence over inequitable land and asset distribution.

Added to this troubling mix, is the fact that the HIV/AIDS epidemic is hitting Namibia particularly hard and continues to have far reaching effects on the labor force and most particularly the agricultural workers who are the majority of all workers in Namibia (70\%). Many of these workers are forced to work only seasonally and under go long periods of time away from homes and family, raising their risk of exposure to HIV/AIDS. They also benefit least from recent labor reform acts guaranteeing minimum wage and compensation and assurance of adequate health and safety measures.

Whatever health and social services are available to farm workers are based on private initiatives, usually from farm owners and employers with limited government support or oversight. This leaves them dependent on the fair practice and good will of corporate or individual landowners for their wellbeing. These services, when offered, add to the rising cost of labor in the competitive global market. The impact of poor land distribution and rising cost of HIV/AIDS services place an extraordinary burden upon the government to enact effective and fair legislation and policies.

The Namibian government's response to the epidemic and to issues of land reform is vital to the nation's survival and the well being of its workers. On a regional level, southern Africa can ill afford further threats to the security and well being of yet another historically "stable" emerging economy. As the effects of HIV/AIDS on the economic and social fabric of the country are so profound, addressing those issues draws upon key governance issues of human rights and equity also at the center of the land tenure struggle.

The Ministries of Labor and Health are currently making a great effort to engage all sectors of government to develop strategies and effective responses to HIV/AIDS including developing workplace policies and programs for care, prevention and support of affected workers and their families. The push for prevention and care services at the workplace are accompanied by a reform in the labor act which guarantees workers rights to safe worksites as well as reasonable accommodation and medical support for those affected by HIV/AIDS

Against this backdrop, the Namibian Ministry of Labor, with support from the US Department of Labor, initiated a project with Futures Group and Project Hope to develop a commercial agricultural sector HIV/AIDS workplace policy. The project also includes work with individual organizations, businesses and farms to draft company specific workplace policies. For the sector policy, extensive consultation and mediation with the two primary unions in the commercial agricultural representing farm workers and farm owners occurred over a period of two years. These meetings resulted in a mutually agreed upon policy reflecting domestic and international labor legislation and standards. 
In a volatile environment of fear and distrust generated by land distribution inequities, traditional adversaries representing farm owners and workers came together to hammer out a sector wide workplace policy addressing HIV/AIDS. Consultative meetings were held in many parts of the country and members of the AIDS Law Unit served as mediators resulting in a signed commercial agricultural sector policy in September of this year.

The policy design process offered an opportunity for farm laborers to educate owners about working conditions, fair labor practices, their more personal frustrations fears and hopes. It also provided an

Opportunity for owners to speak frankly about the very real economic limitations they face in order to effectively compete in the regional and Global markets. The presence of external mediators from the AIDS Law Unit served to keep both parties at the table and lent legitimacy to both perspectives and supported respectful consideration of conflicting concerns. Discussing the principals underlying the HIV/AIDS policy provided an opportunity to reexamine rights and obligations of workers and management in a human rights framework. The same processes, language and values are the cornerstones of effective land reform issues. The ensuing frank and often fractious debates over the rights and responsibilities of the respective partners relating to labor practices and living conditions mirrored the broader political debate in the entire region over worker rights, land tenure and responsibilities of land owners.

In work with individual farming operations, specific workplace HIV/AIDS policies were drafted in a participatory process mediated by Futures Group International and Project Hope staff. These intensive policy development workshops provided an opportunity to observe these struggles close up and in a very personal forum. Farm owners and their representatives had an opportunity to describe the risks and personal cost of running a farm in lean or unstable times. Workers were able to give voice to frustration over low wages, distance to health care services or absence of basic first aid precautions such as gloves and bandages for work related accidents.

In some of these workshops, workers reported feeling devalued by landowners when there was little effort to speak in a shared language or where farm owners were impatient with the slow process of drafting meaningful and realistic workplace policies with newly literate workers. Farm owners reported frustration with worker reluctance to speak in front of a group or ask or answer direct questions. Misunderstandings were frequent but on most occasions discussed and resolved. Every farm that initiated the policy creation process was able to agree upon a final draft that management and workers felt comfortable with and that conformed to the International Labor Union standards as well as current Namibian labor laws.

Policy drafting forums at the sector level as well at the local farm site, introduced owners and workers to international standards of ethical corporate behavior. A representative of management on one farm described the increased pressure on growers to guarantee the health and safety of workers with the ever more rigorous standards of Hygiene and fair labor practices demanded by international buyers associated with the EU. For example, in the southern farming community of Aussenkehr, buyers for a large Dutch chain of super markets visited all the farm sites that they buy from and assessed water and waste management. If a farm did not meet their standards, they were unable to sell that season's harvest.

For land owners in Namibia there is a growing realization that their economic survival is contingent upon maintaining good relations with their workers as well as answering to a strong judicial system and government commitment to rule of law. Addressing work place HIV/AIDS issues with a commitment to the well being of workers can provide an opening for dialogue on other issues vital to the survival of the agricultural sector. This dialogue is fundamental to the creation of robust legislation and policies supporting and protecting fair and equitable treatment of all Namibian citizens whether worker or landowner.

In Aussenkehr, while representatives of workers and management of a large farming concern sat across the table from each other to hammer out an HIV/AIDS workplace policy, across the valley at another farm, workers and owners broke into a brawl over racial tensions and working conditions resulting in severe injuries to two farm owners, resulting in the loss of an eye of one of the injured. The incident captures the tension underlying daily life in Namibia, and the possibility for constructive dialogue side by side with eruptions of chaos and violence. The country's future rests upon how its present leaders respond to the dual challenges of an epidemic affecting the entire labor force as well as finding a way toward equitable land and income distribution. 
Your next submission with Juniper Publishers will reach you the below assets

- Quality Editorial service

- Swift Peer Review

- Reprints availability

- E-prints Service

- Manuscript Podcast for convenient understanding

- Global attainment for your research

- Manuscript accessibility in different formats ( Pdf, E-pub, Full Text, Audio)

- Unceasing customer service

Track the below URL for one-step submission https://juniperpublishers.com/online-submission.php 